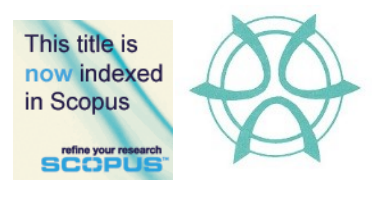

\title{
ASSESSING THE STRATA HOUSING ATTRIBUTES FOR ELDERLY TO AGE IN PLACE IN KLANG VALLEY
}

\author{
Amalina binti Azmi ${ }^{1}$, Peter Aning ${ }^{2}$, Wan Nor Azriyati Wan Abd Aziz $^{3}$, Nur \\ Hafizah Juhari ${ }^{4}$, Nurhayati Khair ${ }^{5}$, Puteri Ameera Mentaza Khan ${ }^{6}$, Sheelah a/p \\ Sivanathan $^{7}$ \\ 1,4,5,6,7 Faculty of Accountancy and Management, \\ UNIVERSITI TUNKU ABDUL RAHMAN (UTAR) \\ ${ }^{2,3}$ Faculty of Built Environment, \\ UNIVERSITIY OF MALAYA
}

\begin{abstract}
As the elderly population is burgeoning globally, the number of elderlies in Malaysia has also increased tremendously. Malaysia is expected to become an aging nation by 2030 . The elderly in Malaysia prefer to age in place. At the same time, the trend of residing in landed property has shifted to strata housing due to several factors. Therefore, the purpose of this study is to assess the strata housing attributes for the elderly to age in place in Klang Valley. The list of housing attributes is divided into three categories: housing features, housing environment and technology. These attributive patterns emerge from various sources of literature reviews. Eight experts were identified and selected to validate the content based on their background as well as their area of specialization.
\end{abstract}

Keywords: Aging, Elderly, Strata Housing, Aging in Place, Housing Attributes

\footnotetext{
${ }^{1}$ Lecturer at University Tunku Abdul Rahman (UTAR). Email: amalina@utar.edu.my
} 
Amalina binti Azmi, Peter Aning, Wan Nor Azriyati Wan Abd Aziz, Nur Hafizah Juhari, Nurhayati Khair, Puteri Ameera Mentaza Khan, Sheelah a/p Sivanathan,

Assessing the Strata Housing Attributes for Elderly to Age in Place in Klang Valley

\section{INTRODUCTION}

The aging population is burgeoning globally, including in Malaysia. Malaysia is predicted to become an aging nation by the year 2030. The elderly population increases are due to factors such as low birth rate, low fertility rate, low mortality rate and increased life expectancy. However, as an elderly, they experienced impairments such as primary functional impairment, chronic disease, diminishing social network, and lower level of physical activities (Peek et al., 2014; Wilby \& Cathy Chambless, 2012).

However, previous research discovered that most elderly prefer to age in place regardless of their impairments. Aging in place is defined as the ability to live in one's own home and community safely, independently, and comfortably, regardless of age, income, and ability level (Lum et al., 2016). They prefer to age in place to maintain control and autonomy in their lives to ensure their wellbeing and quality of life (Coleman \& Kearns, 2015). It is also revealed that the elderly tend to choose a smaller house namely strata housing such as apartments, townhouses, and condominiums (Guillory \& Moschis, 2008; Judd et al., 2012; Vasara, 2015). Thus, the elderly require an innovative housing design for them to age in place safely and comfortably (Thompson, 2013).

In Malaysia, the increasing population and limited land offered have forced high-rise buildings to become a lifestyle (Che Ani et al., 2010). However, the homes and communities in Malaysia are not designed to meet people's needs as they grow older. Moreover, according to the mid-term review of the $11^{\text {th }}$ Malaysia Plan, one of the challenges of the increasing number of elderlies is the lack of collaboration between agencies in implementing the universal design for building and public facilities. Consequently, it has reduced the efforts to provide a user-friendly physical environment, especially for the elderly (Ministry of Economic Affairs, 2018). On top of that, under Strategy 4 of the $11^{\text {th }}$ Malaysia Plan, various measures need to be considered to enhance the elderly living environment.

Initiatives such as age-friendly community, lifelong learning and retirement village concept will be promoted as the independent living lifestyle. The mid-term review also urged the private sector to embrace the creation of a lively community, housing and local areas. It is also imperative that the location is near public amenities and transit terminals. Environment-friendly facilities such as parks and recreation spaces need to be provided (Ministry of Economic Affairs, 2018). Many previous local scholars have studied the housing attributes for the elderly to age in place in landed properties (Tobi et al., 2017; Zainab Ismail et al., 2012), but there are limited studies on housing attributes for the elderly to age in place in strata housing (Sitinur Athirah et al., 2016; Wai \& Wei, 2016). In addition, Tan \& Lee (2018) claimed that the housing needs and preferences of the 
elderly are lacking in Malaysia. Thus, this study will assess the attributes of strata housing needed by the elderly to age in place in Klang Valley.

\section{RESEARCH BACKGROUND \\ The Aging Population}

The aging population has increased tremendously worldwide. Most of the developed countries have categorized 65-year-olds as elderly (Rosilawati \& Pettit, 2016). Meanwhile, in most of the developing countries, including Malaysia, 60 years old are grouped as elderly (Siti Uzairah et al., 2018). In Malaysia, Jariah, Husna, Aizan, \& Ibrahim (2012) identified that the Ministry of Women, Family, and Community Development of Malaysia affirmed that someone who is above 60 years of age could be considered elderly. This follows the guideline by the United Nations World Assembly on Ageing 1982 in Vienna. According to the Malaysian Department of Statistics, there were about 2.7 million senior citizens in 2014, forming $8.9 \%$ out of the 30.3 million Malaysian population. Hence, Malaysia is expected to become an aging nation by the year 2030.

Yüksel, Kırkkanat, Yılmaz, \& Sevim (2016) specified that the characteristics of the elderly could be divided into psychological and physiological aspects. The psychological aspect is indicated by the state of emotion of the elderly. The positive emotions are when the elderly feel satisfied with their lives and the negative emotions are when they feel unsatisfied with their lives, feeling isolated and alienated (Pavalache-Ille, 2015). On the other hand, the physiological aspect is related to physical illness (Abdul Manaf et al., 2016). Frailty among the elderly is evident in the increase of weakness and slowness that usually leads to a decline in daily activities, causing fatal accidents (Yuki et al., 2016). In addition, Gonawala et al. (2013) mentioned that the elderly also endanger themselves on the road caused by their decreasing vision, lack of hearing ability, increased cognitive impairment, and confusion.

As the global population is aging, societies around the world are struggling with the issues and problems related to providing care for the aging population in their homes. Lipman, Lubell, \& Salomon (2012) found increased demands for home modification to enable the elderly to age in place. In addition, Mohd, Senadjki, \& Mansor (2017) highlighted that number of elderly living alone across 43 countries, including Malaysia, is increasing to the extent that almost a quarter of them live by themselves. Furthermore, most elderly wish to age in place in a strata housing (Ainoriza et al., 2016). The trend to prefer living in a strata housing is due to factors such as land scarcity, high price for landed property, facilities in strata housing and many other factors (Ainoriza et al., 2017; Shuid, 2004; Siti Rashidah Hanum et al., 2016). Therefore, this study will assess the strata housing attributes to cater to the elderly needs to age in place using the 
Amalina binti Azmi, Peter Aning, Wan Nor Azriyati Wan Abd Aziz, Nur Hafizah Juhari, Nurhayati Khair, Puteri Ameera Mentaza Khan, Sheelah a/p Sivanathan,

Assessing the Strata Housing Attributes for Elderly to Age in Place in Klang Valley

content validation method which will be explained in the next section.

\section{METHODOLOGY}

In order to answer the research questions and attain the research objective, which is to identify the strata housing attributes that fulfil the elderly needs to age in place, various housing attributes were identified from various literature reviews and validations of experts. Content Validation has been conducted to validate the attributes that emerged from the review of various literature. Rossiter (2010) stated that selecting at least three experts are advisable in conducting content validity via interviews. In this research, 8 experts were chosen to validate the content based on their areas of specialization, as indicated in Table 1.

Table 1: Experts Involved in Content Validation

\begin{tabular}{|c|c|c|}
\hline $\begin{array}{c}\text { No of } \\
\text { Experts }\end{array}$ & Category of Expert & Area of Specialization \\
\hline 2 & NGO & Aging society \\
\hline 2 & Academician & Research related to elderly \\
\hline 2 & Government agency & Jabatan Kebajikan Masyarakat \\
\hline 2 & Developer & Sustainable development \\
\hline
\end{tabular}

The content obtained from the literature review was divided into three sections. Section A comprises the housing features, including the entrance, hallway, living room, toilet, bedroom, kitchen and balcony. Meanwhile, Section B consists of the housing environment; the housing environment for the elderly is based on accessibility, safety, security, other services, and facilities. The final category is Section $\mathrm{C}$ which is concerned with technology - an exploration of the participant's knowledge and opinions regarding the usage of mobile devices, telecommunication link such as fibre optic, Wi-Fi, intercom, television and clocking.

\section{RESULT}

Table 2 illustrates the content features that had been validated by the experts, including non-government organizations, academics, developers, and government authorities. The attributes were discovered from various reviews of literature, comprising the entrance, hallway, living room, toilet, bedroom kitchen, and balcony. They also validated the housing environment features, namely accessibility, safety, security, and other services, including the lift, open space or green park, car park, multi-language signboards, and multipurpose hall. On top of that, the experts also validated technological features such as individual mobile 
devices, i.e., smartphone or tablet and telecommunication links, i.e. fibre optic, Wi-Fi, internet, intercom, television, and clocking.

Table 2: Content Analysis

\begin{tabular}{|c|c|c|}
\hline \multicolumn{3}{|r|}{ Housing Attributes } \\
\hline \multirow{5}{*}{$\begin{array}{l}\text { Housing } \\
\text { features }\end{array}$} & House Type & High-rise \\
\hline & Entrance & $\begin{array}{l}\text { - Bench } \\
\text { - Sliding door } \\
\text { - Lightweight door with doorknob height is not more than } \\
\text { - } 1.2 \mathrm{~m} \\
\text { - } \text { Woor equipped with thumb print scanner } \\
\end{array}$ \\
\hline & Hallway & $\begin{array}{l}\text { - } \text { Equipped with grab bar } \\
\text { - Sufficient lighting } \\
\text { - Barrier free }\end{array}$ \\
\hline & Living room & $\begin{array}{l}\text { - Size (minimum } 2.5 \mathrm{~m}) \\
\text { - Separate living room and dining area } \\
\text { - Sufficient lighting } \\
\text { - Sufficient ventilation } \\
\text { - Electrical socket }(800 \mathrm{~mm}-1.1 \mathrm{~m} \text { from the floor level, } \\
\text { waist level, and visible) } \\
\text { - Anti-skid flooring } \\
\text { - Bright colour } \\
\text { - Living room facing swimming pool, garden, park, road, } \\
\text { or different unit }\end{array}$ \\
\hline & Toilet & $\begin{array}{l}\text { - Has handrails/toilet grab bar } \\
\text { - Has alarm/emergency button } \\
\text { - Has anti-skid flooring } \\
\text { - Has flat entrance with tactile waning indicator } \\
\text { - Has wide doorways (minimum width is } \\
1200 \mathrm{~mm}) / \text { sliding door } \\
\text { - Has water tap/shower head with sensor } \\
\text { - Large in size (minimum width is } 2400 \mathrm{~mm}, \text { minimum } \\
\text { - length is } 2000 \mathrm{~mm}) \\
\text { - Squat toilet } \\
\text { - } \text { Seated water closet } \\
\text { - Hached to bedroom } \\
\text { - Regularly maintained and cleaned } \\
\text { - Split toilet and bathroom }\end{array}$ \\
\hline
\end{tabular}


Amalina binti Azmi, Peter Aning, Wan Nor Azriyati Wan Abd Aziz, Nur Hafizah Juhari, Nurhayati Khair, Puteri Ameera Mentaza Khan, Sheelah a/p Sivanathan,

Assessing the Strata Housing Attributes for Elderly to Age in Place in Klang Valley

\begin{tabular}{|c|c|c|}
\hline & Bedroom & $\begin{array}{l}\text { - Has adequate lighting fittings } \\
\text { - Has access to natural daylight } \\
\text { - Ample in size (minimum } 1000 \mathrm{~mm} \text { x } 2000 \mathrm{~mm}) \\
\text { - Has electrical socket ( } 800 \mathrm{~mm}-1000 \mathrm{~mm} \text { from the floor } \\
\text { level, waist level and visible) } \\
\text { - Equipped with alarm/emergency button } \\
\text { - Has intercom connected to security guard house }\end{array}$ \\
\hline & Kitchen & $\begin{array}{l}\text { - Is wide (sufficient space for walking aids and for } \\
\text { wheelchair access, between } 1800 \mathrm{~mm}-2000 \mathrm{~mm} \text { ) } \\
\text { - Kitchen with compartment/partition (closed/hidden } \\
\text { kitchen) } \\
\text { - Equipped with manual equipment (using gas) } \\
\text { - Equipped with electrical appliances (induction cooker, } \\
\text { electric kettle, rice cooker, et cetera) } \\
\text { - Has anti-skid floor finishes } \\
\text { - Has gas leaking sensor } \\
\text { - Has smoke detector } \\
\text { - Has fire extinguisher and fire protector }\end{array}$ \\
\hline & Balcony & $\begin{array}{l}\text { - Large in size, equipped with handrails, has a good view } \\
\text { facing swimming pool, garden/park, road, or different } \\
\text { unit }\end{array}$ \\
\hline \multirow[t]{3}{*}{$\begin{array}{l}\text { Housing } \\
\text { environm } \\
\text { ent }\end{array}$} & $\begin{array}{l}\text { Location or } \\
\text { distance }\end{array}$ & $\begin{array}{l}\text { - Near to friends and family } \\
\text { - Close to amenities (groceries, wet market, supermarket) } \\
\text { - Close to recreational parks / centre } \\
\text { - Close to public transportation (train station, bus station) } \\
\text { - Close to medical centre (pharmacies, clinic, hospital) } \\
\text { - Close to banks/ATM/saloon } \\
\text { - Close to dining (restaurants, canteen) } \\
\text { - Close to worship place (surau/masjid, temple, church) }\end{array}$ \\
\hline & $\begin{array}{l}\text { Safety, } \\
\text { security and } \\
\text { other } \\
\text { services }\end{array}$ & $\begin{array}{l}\text { - Has thumb print door access } \\
\text { - Has safe crosswalks/pedestrian cross } \\
\text { - Has speed bump } \\
\text { - Has street lighting } \\
\text { - Has cleaning service/maid service } \\
\text { - Has garbage chute service } \\
\text { - Gated/guarded } \\
\text { - 24-hour neighbourhood surveillance }\end{array}$ \\
\hline & Lift & $\begin{array}{l}\text { Large in size (minimum size is } 1100 \mathrm{~mm} \times 1400 \mathrm{~mm} \text {, } \\
630 \mathrm{~kg}) \\
\text { - Has sufficient ventilation } \\
\text { - Close to lobby } \\
\text { - Has chairs at the lobby } \\
\text { - Has handrail on the three sides }(1000 \mathrm{~mm} \text { from the floor } \\
\text { level) } \\
\text { - Has mirror located opposite of the lift door }\end{array}$ \\
\hline
\end{tabular}




\begin{tabular}{|c|c|c|}
\hline & & - The highest button is not higher than $1400 \mathrm{~mm}$ \\
\hline & $\begin{array}{l}\text { Open space } \\
\text { or green } \\
\text { parks }\end{array}$ & $\begin{array}{l}\text { - Has gardening space } \\
\text { - Has activity space } \\
\text { - Has benches and tables } \\
\text { - Has reflexology track } \\
\text { - Has community society } \\
\text { - Has ramp with tactile warning indicator } \\
\text { - Has walking path } \\
\text { - Has basic exercise equipment }\end{array}$ \\
\hline & Car park & $\begin{array}{l}\text { - Elevated car park } \\
\text { - Ground covered car park } \\
\text { - Ample size of car park (minimum width is } 3600 \mathrm{~mm} \text {, } \\
\text { minimum length is } 5400 \mathrm{~mm} \text { and minimum transfer array } \\
\text { is } 1200 \mathrm{~mm}) \\
\text { - Direction signage for designated parking and other } \\
\text { facilities }\end{array}$ \\
\hline & Others & $\begin{array}{l}\text { There are multi-language signboards consists of } \\
\text { information, symbol, and direction } \\
\text { - Multipurpose hall }\end{array}$ \\
\hline Technolo & & - Individual mobile devices like smartphone and tablet \\
\hline & & $\begin{array}{l}\text { - Telecommunication link (fibre optic/Wi- } \\
\text { Fi/internet/intercom) } \\
\text { - Television } \\
\text { - Clocking } \\
\end{array}$ \\
\hline
\end{tabular}

\section{DISCUSSION}

Based on the results, an unobstructed door with a width of a minimum of $850 \mathrm{~mm}$; 900mm or more is recommended in MS1184:2014 (Zaid et al., 2019). Mei-yung (2017) highlighted that sliding doors are convenient to the elderly and encourage independence among the elderly. Next is the attributes of the hallway. Rieh (2018) mentioned that the presence of grab bars inside a house is crucial to assist the elderly gain mobility and, at the same time ensure their safety. Mei-yung Leung et al. (2019) further added that a grab bar enables the elderly to be more independent and mobile in accomplishing their daily activities. Based on Lee \& Yoo (2020) research, it is found that the wide size of a hallway will provide convenience to the elderly. According to Russell et al. (2019), good lighting is another important feature, as poor lighting can cause a fall and other accidents among the elderly in their houses.

Moving on to the living room attributes, Mei-yung (2017), mentioned that building orientation is important to provide natural lighting and good 
Amalina binti Azmi, Peter Aning, Wan Nor Azriyati Wan Abd Aziz, Nur Hafizah Juhari, Nurhayati Khair, Puteri Ameera Mentaza Khan, Sheelah a/p Sivanathan,

Assessing the Strata Housing Attributes for Elderly to Age in Place in Klang Valley

ventilation, which will increase the quality of life of the elderly. According to Rieh (2018), the living room is one of the important attributes for the elderly as they spend most of their time watching TV, reading and doing activities associated with their hobbies. Moreover, Chen, Zhu, \& Xiong (2018) highlighted that lighting provides a pleasant mood, increases alertness, and enables the elderly to stay vigilant. In addition, Datta (2019) found that good ventilation in a room or space is very important in determining a good quality of life for the elderly. Mei-yung (2017) further added that good ventilation would ensure the elderly's health by maintaining the elderly's body temperature. Mei-yung Leung, $\mathrm{Yu}, \&$ Chow (2016) also mentioned that a moderate height of electrical sockets enables the elderly to be more independent.

Akbar, Ramadhani, \& Putri (2018)'s research findings revealed that a smoke detector is an assistive technology that can detect the presence of fire. A heat detector in the kitchen provides additional protection against the risk of fires, and it is exposed to fire when the temperature hit $62^{\circ} \mathrm{C}$ (Palumbo et al., 2014). It is important for the elderly's security and provides appropriate warning during emergency situation as well as to avoid fire accidents and death (Akbar et al., 2018; Feng et al., 2018). Feng et al. (2018), in their research, highlighted that anti-skid flooring will prevent falling and accidents among the elderly.

Anti-skid flooring in a toilet is important for the elderly to protect them from accidents and falling (Afifi et al., 2015; Clemson et al., 2019). In addition, according to Abdel Salam \& Shams El-din (2019), a grab bar in the toilet or bathroom will enable the elderly to move around. Abdel Salam \& Shams El-din (2019) further added that the emergency button in the bathroom should be waterproof and color contrasted, to increase the safety of the elderly. Katunský $\&$ Brausch (2018) asserted that tactile features are essential to increase visual and sensory cognition among the elderly. According to (Carr et al., 2013), sliding doors will provide accessibility for the elderly to enter a space and reduce the need for them to open a heavy door. Opening a heavy door can cause negative feelings among the elderly as they have very limited energy (M. Y. Leung et al., 2017). Moreover, the sliding door will also enable the elderly with a wheelchair to access the toilet or bathroom (van Hoof \& Boerenfijn, 2018).

According to Abdel Salam \& Shams El-din (2019), water faucets with sensors in the bathroom can assist the elderly who find it is difficult to turn the manual faucet, and at the same time, they will reduce water usage. Based on Afifi et al. (2015), a seated water closet will enable the elderly to stand with the support of the installed grab bar in the toilet. Mirror located next to the washbasin also promotes comfort and safety to the elderly (Paiva et al., 2015). According to Feng et al. (2018), even flooring is also fundamental for the elderly to avoid impediments, while cleanliness is also important to prevent contagious and skin 
diseases. Mei-yung (2017) highlighted that the use of contrasting colors in a building could reduce confusion among the elderly.

According to Gardner (2011), a balcony is very important for the elderly to feel connected to their neighbour. Al-Shaqi, Mourshed, \& Rezgui (2016); Gardner (2011); Verma (2019) mentioned that businesses and services such as banks, groceries store, restaurants and others are important for the elderly who wish to age in place as those businesses and services enable the elderly to maintain their social network.

On the other hand, Lehmann, Syrdal, Dautenhahn, Gelderblom, \& Bedaf (2013); Weeks \& LeBlanc (2010) highlighted the importance of a safe and secured neighbourhood. Day, Boarnet, Alfonzo, \& Forsyth (2006); Haselwandter et al. (2015) stated that safety aspects include safety from crimes, the provision of street lighting, neighbourhood surveillance, and protection from traffic like safe crosswalks, bike lanes, and sidewalks. Gated and guarded communities and the availability of 24-hour surveillance cameras are important for the elderly to prevent snatch thefts, house break-ins, and rampant. Having a few street lightings in the surrounding area to assist the elderly in walking and giving a comfortable view at night is imperative

According to Loukaitou-Sideris, Wachs, \& Pinski (2019), proper lighting is an attribute to increase road safety for the elderly. Speed bumps are important to slow down the approaching vehicles (Loukaitou-Sideris \& Wachs, 2018). Pedestrian lanes are believed to reduce the risk of accidents and, at the same time, increase safety (Verma, 2018). According to Nadine (2019), a garbage chute will ease the elderly in managing waste from their house. Farzana $\&$ Tanmoy (2019) added that maid service is important for the elderly to help them manage their basic necessities while aging in place.

Lift is essential in strata housing. Based on the results, a mirror in a lift is an attribute. The function of a mirror in the lift is to assist the elderly who are in a wheelchair to observe any obstacles behind them when they are unable to turn around and move backwards (Department of Standards Malaysia, 2014). Mei Yung Leung \& Liang (2019), in their research, stated that a lift is important for the elderly to connect with their external environment when living in high-rise buildings. They further added that the lift should be elderly sensitive by providing benches for resting. Moreover, according to Yuen (2019), a grab bar is important in a lift to assist the elderly to age in place.

Open space is important for the elderly to encourage social interaction and, at the same time, ensure successful aging (Yung et al., 2016). Moreover, according to Yung et al. (2016), WHO (2007) has identified 11 elements to revitalize open spaces for the elderly, which include green spaces, walkways, outdoor seating, pavements, roads, traffic, cycle paths, safety, services, buildings and public toilets. According to Arnberger et al. (2017) and Paiva et al. (2015), 
Amalina binti Azmi, Peter Aning, Wan Nor Azriyati Wan Abd Aziz, Nur Hafizah Juhari, Nurhayati Khair, Puteri Ameera Mentaza Khan, Sheelah a/p Sivanathan,

Assessing the Strata Housing Attributes for Elderly to Age in Place in Klang Valley

benches in the garden and outside space are important for elderly as resting points along the route. Darmawati (2019) asserted that open space or green space will be able to reduce the elderly's stress level, hence attractive open space or green space is necessary to increase the elderly's interaction. In addition, activities suitable for the elderly are considered social therapy for them (Darmawati, 2019). Besides, green space will be able to reduce the temperature by providing shading for outside activities (Arnberger et al., 2017). Loukaitou-Sideris, Levy-Storms, Chen, \& Brozen (2016), further added, parks will increase the social interaction among the elderly. Social and recreational activities are said to improve the elderly's health (Mei-yung, 2017).

On the other hand, proper signage can assist the elderly to be independent (Mei-yung, 2017). Wei, Kiang, \& Chye (2017) highlighted that a multipurpose hall is a critical attribute for aging in place in order to encourage and provide shared space for common use. Mei-yung (2017) further added that facilities that can cater to multipurpose activities are essential in improving the elderly's quality of life.

In addition, technologies must also be anticipated in designing a house for the elderly to help them overcome their weaknesses (Wright et al., 2014). According to Nordin et al. (2017), most elderly who live in an apartment usually engage in recreational activities such as watching television or listening to the radio. Hence, those attributes are important. At the same time, those attributes provide a valuable link to the outside world and society. At the same time, television will enable the elderly to live independently, remain active and stay healthy (Peek et al., 2016). Smartphones allow the elderly to have social interaction and social engagement to increase their quality of life (Wang et al., 2019). In addition, in their research, Joe et al. (2018) mentioned that the elderly could use their phones for health and wellness interventions, including management of diabetes, symptom management, and fall detection. According to Casado-Muñoz, Lezcano, \& Rodríguez-Conde, (2015); Tatnall \& Lepa (2003), telecommunication or internet is important for the elderly to enable them to communicate with their family and friends through email, to access information, to perform e-commerce activities such as paying bills, purchase of goods and services and electronic banking.

\section{SUMMARY}

From the theoretical perspective, the implications of this study are manifolds. First, the findings contribute to the growing body of knowledge in housing that enables the elderly to age in place in Malaysia. The suggested attributes for all the strata housing will enable the elderly to age in place gracefully, with less risk of hazards and accidents. The discovered housing attributes can be developed as a guideline for the elderly in Malaysia to age in place in strata housing. Moreover, 
it will contribute towards the formulation and monitoring of more effective policies to promote aging in place.

\section{ACKNOWLEDGEMENTS}

This research has been accomplished with financial support from the Real Estate Research and Development Grant Scheme (NAPREC) represented by the National Institute of Valuation (INSPEN). Universiti Tunku Abdul Rahman (UTAR) Sungai Long Campus gratefully acknowledges the financial and other support it has received from the Government of Malaysia.

\section{REFERENCES}

Abdel Salam, M., \& Shams El-din, A. (2019). Developing Smarter Bathrooms for Elderly and Disabled People. Journal of Al-Azhar University Engineering Sector, 14(52), 1024-1035. https://doi.org/10.21608/auej.2019.42295

Abdul Manaf, M. R., Mustafa, M., Abdul Rahman, M. R., Yusof, K. H., \& Abd Aziz, N. A. (2016). Factors influencing the prevalence of mental health problems among Malay elderly residing in a rural community: A cross-sectional study. PLoS ONE, 11(6), 1-12. https://doi.org/10.1371/journal.pone.0156937

Afifi, M., Al-Hussein, M., \& Bouferguene, A. (2015). Geriatric bathroom design to minimize risk of falling for older adults- A systematic review. European Geriatric Medicine, 6(6), 598-603. https://doi.org/10.1016/j.eurger.2015.05.004

Ainoriza, M. A., Nooraisyilah, M., \& Wan Nor Azriyati, W. A. A. (2016). Housing Aspirations of the Elderly in Malaysia : A Comparison of Urban and Rural Areas. Journal of Design and Built Environment, 16(2).

Ainoriza, M. A., Wan Nor Azriyati, W. A. A., \& Nurul Farahana, Z. (2017). Middle Adults ' Housing Expectations for Old -age : A Study of Urban Area of Greater Kuala Lumpur. Journal of Design and Built Environment, 150-165.

Akbar, M. F., Ramadhani, N. A., \& Putri, R. A. (2018). Assistive and wearable technology for elderly. Bulletin of Social Informatics Theory and Application, 2(1), 8-14. https://doi.org/10.31763/businta.v2i1.101

Al-Shaqi, R., Mourshed, M., \& Rezgui, Y. (2016). Progress in ambient assisted systems for independent living by the elderly. SpringerPlus, 5(1), 624. https://doi.org/10.1186/s40064-016-2272-8

Arnberger, A., Allex, B., Eder, R., Ebenberger, M., Wanka, A., Kolland, F., Wallner, P., $\&$ Hutter, H. P. (2017). Elderly resident's uses of and preferences for urban green spaces during heat periods. Urban Forestry and Urban Greening, 21, 102-115. https://doi.org/10.1016/j.ufug.2016.11.012

Carr, K., Weir, P. L., Azar, D., \& Azar, N. R. (2013). Universal Design : A Step toward Successful Aging. Journal of Aging Research, 2013.

Casado-Muñoz, R., Lezcano, F., \& Rodríguez-Conde, M. J. (2015). Active ageing and access to technology: An evolving empirical study. Comunicar, 23(45), 37-46. https://doi.org/10.3916/C45-2015-04

Che Ani, A. ., Tawil, N. ., Sairi, A., Abdullah, N. A. ., Tahir, M. ., \& Surat, M. (2010). Facility Management Indicators for High-Rise Residential Property in Malaysia. 
Amalina binti Azmi, Peter Aning, Wan Nor Azriyati Wan Abd Aziz, Nur Hafizah Juhari, Nurhayati Khair, Puteri Ameera Mentaza Khan, Sheelah a/p Sivanathan,

Assessing the Strata Housing Attributes for Elderly to Age in Place in Klang Valley

WSEAS Transactions on Environment and Development, 6(4), 255-264.

Clemson, L., Stark, S., Pighills, A. C., Torgerson, D. J., Sherrington, C., \& Lamb, S. E. (2019). Environmental interventions for preventing falls in older people living in the community. Cochrane Database of Systematic Reviews, 2019(2). https://doi.org/10.1002/14651858.CD013258

Coleman, T., \& Kearns, R. (2015). The role of bluespaces in experiencing place, aging and wellbeing: Insights from Waiheke Island, New Zealand. Health and Place, 35, 206-217. https://doi.org/10.1016/j.healthplace.2014.09.016

Darmawati, R. (2019). Perception of Green Open Space as Medium of Therapy for Elderly. MATEC Web of Conferences, 280, 03018. https://doi.org/10.1051/matecconf/201928003018

Datta, T. (2019). Living arrangements of the elderly in Fiji. Genus Homo, 3, 61-72.

Day, K., Boarnet, M., Alfonzo, M., \& Forsyth, A. (2006). The Irvine-Minnesota inventory to measure built environments: Development. American Journal of Preventive Medicine, 30(2), 144-152. https://doi.org/10.1016/j.amepre.2005.09.017

Department of Standards Malaysia. (2014). MS1184: 2014 Universal design and accessibility in the built environment- Code of practice (Second Revision).

Farzana, F., \& Tanmoy, M. (2019). 'Aging in Place' in Bangladesh : Challenges and Possibilities. International Journal of Multidiscplinary Research, 4(2), 23-42. https://doi.org/10.5281/zenodo.3593329

Feng, I. M., Chen, J. H., Zhu, B. W., \& Xiong, L. (2018). Assessment of and improvement strategies for the housing of healthy elderly: Improving quality of life. Sustainability (Switzerland), 10(3), 1-32. https://doi.org/10.3390/su10030722

Gardner, P. J. (2011). Natural neighborhood networks - Important social networks in the lives of older adults aging in place. Journal of Aging Studies, 25(3), 263-271. https://doi.org/10.1016/j.jaging.2011.03.007

Gonawala, R. J., Badami, N. B., Electicwala, F., \& Kumar, R. (2013). Impact of Elderly Road Users Characteristics at Intersection. Procedia - Social and Behavioral Sciences, 104(0), 1088-1094. https://doi.org/10.1016/j.sbspro.2013.11.204

Guillory, M. D., \& Moschis, G. (2008). Marketing Apartments , Townhouses , and Condominiums to Seniors. Seniors Housing \& Care Journal, 16(1), 39-52.

Haselwandter, E. M., Corcoran, M. P., Folta, S. C., Hyatt, R., Fenton, M., \& Nelson, M. E. (2015). The built environment, physical activity, and aging in the United States: A state of the science review. Journal of Aging and Physical Activity, 23(2), 323 329. https://doi.org/10.1123/japa.2013-0151

Jariah, M., Husna, S., Aizan, T., \& Ibrahim, R. (2012). SOCIAL SCIENCES \&amp; HUMANITIES Financial Practices and Problems amongst Elderly in Malaysia. Pertanika J. Soc. Sci. \& Hum, 20(4), 1065-1084. http://www.myjurnal.my/filebank/published_article/26015/09_Page_1065_1084. pdf

Judd, B., Bridge, C., Davy, L., Adams, T., \& Liu, E. (2012). Downsizing amongst older Australians. In AHURI Positioning Paper (Issue 150). http://staging.beweb.fbe.unsw.edu.au/sites/default/files/upload/research/centres/c f/publications/ahuriprojectreports/AHURI_Positioning_Paper_No150.pdf

Katunský, D., \& Brausch, C. (2018). Environmental Issues Related to the Elderly and 
PLANNING MALAYSIA

Journal of the Malaysia Institute of Planners (2021)

Physically Disabled People in Different Life Situations. https://doi.org/10.20944/preprints201807.0282.v1

Lee, S. Y., \& Yoo, S. E. (2020). WILLINGNESS TO PAY FOR ACCESSIBLE ELDERLY HOUSING IN KOREA. International Journal of Strategic Property Management, 24(1), 70-82.

Lehmann, H., Syrdal, D., Dautenhahn, K., Gelderblom, G. J., \& Bedaf, S. (2013). What Should a Robot do for you ? - Evaluating the Needs of the Elderly in the UK. Achi 2013, c, 83-88.

Leung, M. Y., Famakin, I. O., \& Olomolaiye, P. (2017). Effect of facilities management components on the quality of life of Chinese elderly in care and attention homes. Facilities, 35(5-6), 270-285. https://doi.org/10.1108/F-03-2016-0032

Leung, Mei-yung, Famakin, I. O., \& Wang, C. (2019). Developing an integrated indoor built environment - quality of life model for the elderly in public and subsidized housing. Engineering, Construction and Architectural Management. https://doi.org/10.1108/ECAM-02-2018-0054

Leung, Mei-yung, Yu, J., \& Chow, H. (2016). "Impact of indoor facilities management on the quality of life of the elderly in public housing." Facilities, 34(9/10), 564 579.

Leung, Mei yung, \& Liang, Q. (2019). Developing structural facilities managementquality of life models for the elderly in the common areas of public and subsidized housings. Habitat International, 94(October), 102067. https://doi.org/10.1016/j.habitatint.2019.102067

Lipman, B., Lubell, J., \& Salomon, E. (2012). Housing an aging population: are we prepared? In Introduction to Housing.

Loukaitou-Sideris, A., Levy-Storms, L., Chen, L., \& Brozen, M. (2016). Parks for an Aging Population: Needs and Preferences of Low-Income Seniors in Los Angeles. Journal of the American Planning Association, 82(3), 236-251. https://doi.org/10.1080/01944363.2016.1163238

Loukaitou-Sideris, A., \& Wachs, M. (2018). Transportation for an Aging Population: Promoting Mobility and Equity for Low-Income Seniors. http://transweb.sjsu.edu

Loukaitou-Sideris, A., Wachs, M., \& Pinski, M. (2019). Toward a Richer Picture of the Mobility Needs of Older Americans. Journal of the American Planning Association, 85(4), 482-500. https://doi.org/10.1080/01944363.2019.1630295

Lum, T. Y. S., Lou, V. W. Q., Chen, Y., Wong, G. H. Y., Luo, H., \& Tong, T. L. W. (2016). Neighborhood Support and Aging-in-Place Preference Among LowIncome Elderly Chinese City-Dwellers. Journals of Gerontology Series B: Psychological Sciences and Social Sciences, 71(1), 98-105. https://doi.org/10.1093/geronb/gbu154

Mei-yung, L. (2017). Effect of facilities management components on the quality of life of Chinese elderly in care and attention homes. Facilities, 35(5/6), 270-285. https://doi.org/10.1108/F-03-2016-0032

Ministry of Economic Affairs. (2018). Mid-Term Review of the Eleventh Malaysia Plan, 2016-2020: New Priorities and Emphases. Percekan Nasional Malaysia Berhad.

Nadine, A. (2019). RETHINK Aging in Place: An Integrated Indoor Domestic Waste Management System (Issue April). 
Amalina binti Azmi, Peter Aning, Wan Nor Azriyati Wan Abd Aziz, Nur Hafizah Juhari, Nurhayati Khair,

Puteri Ameera Mentaza Khan, Sheelah a/p Sivanathan,

Assessing the Strata Housing Attributes for Elderly to Age in Place in Klang Valley

Nordin, S., McKee, K., Wallinder, M., von Koch, L., Wijk, H., \& Elf, M. (2017). The physical environment, activity and interaction in residential care facilities for older people: a comparative case study. Scandinavian Journal of Caring Sciences, 31(4), 727-738. https://doi.org/10.1111/scs.12391

Paiva, M., Ferrer, N., \& Villarouco, V. (2015). The process of aging: A case study approach implementing an ergonomics evaluation of the built environment for the elderly in Brazil. Work, 50(4), 595-606.

Palumbo, F., Ullberg, J., Stimec, A., Furfari, F., Karlsson, L., Coradeschi, S., \& Pontecorvo, L. B. (2014). Sensor Network Infrastructure for a Home Care Monitoring System 4. 3833-3860. https://doi.org/10.3390/s140303833

Pavalache-Ille, M. (2015). Appropriation of space and well-being of institutionalized elderly people. Journal Plus Education, 3(SI), 201-206.

Peek, S. T. M., Luijkx, K. G., Rijnaard, M. D., Nieboer, M. E., Van Der Voort, C. S., Aarts, S., Van Hoof, J., Vrijhoef, H. J. M., \& Wouters, E. J. M. (2016). Older Adults' Reasons for Using Technology while Aging in Place. Gerontology, 62(2), 226-237. https://doi.org/10.1159/000430949

Peek, S. T. M., Wouters, E. J. M., van Hoof, J., Luijkx, K. G., Boeije, H. R., \& Vrijhoef, H. J. M. (2014). Factors influencing acceptance of technology for aging in place: A systematic review. International Journal of Medical Informatics, 83(4), 235 248. https://doi.org/10.1016/j.ijmedinf.2014.01.004

Rieh, S. Y. (2018). Post-occupancy evaluation of urban public housing in Korea: Focus on experience of elderly females in the ageing society. Indoor and Built Environment, O(0), 1-17. https://doi.org/10.1177/1420326X18782578

Rosilawati, Z., \& Pettit, C. J. (2016). Faculty of Built Environment. Malaysian Institute of Planners, $V$, 49-64.

Rossiter, J. . (2010). Measurement for the social science: The C-OAR-SE method and why it must replace psychometrics. Springer Science \& Business Media.

Russell, D., Oberlink, M. R., Onorato, N., Feinberg, J. L., Bowles, K. H., \& Szanton, S. L. (2019). Identifying Barriers in the Home Environment among Urban Community-Dwelling Older Adults with Functional Difficulty: A Multi-Method Pilot Study. Activities, Adaptation and Aging, 43(4), 315-333. https://doi.org/10.1080/01924788.2018.1542247

Saidatulakmal, M., Senadjki, A., \& Norma, M. (2016). Living Arrangements of Elderly: Evidence from Household Income Expenditure Survey. Journal of Population Ageing, 10(4), 323-342.

Shuid, S. (2004). URBANIZATION AND HOUSING IN KUALA LUMPUR CITY CENTRE: ISSUES AND FUTURE CHALLENGES. 19th Earoph World Planning and Housing Congress, 1-14.

Siti Rashidah Hanum, A. W., Adi Irfan, C. A., Sairi, A., Norngainy, M. T., \& Mohd Zulhanif, A. R. (2016). Classification of High-Rise Residential Building Facilities: A Descriptive Survey on 170 Housing Scheme in Klang Valley. MATEC Web of Confrence, 66, 00103.

Siti Uzairah, M. T., Mohamad Syazli, F., \& Amaratunga, D. (2018). Ageing In Place Framework As Reference Guide For Housing In Malaysia: Landed Property. Journal of the Malaysian Institute of Planners, 16(1), 130-143. 
Siti Uzairah, M. T., Mohd Syazli, F., \& Amaratunga, D. (2017). Ageing in place, an overview for the elderly in Malaysia. AIP Conference Proceedings, 1891(1), 020101. https://doi.org/10.1063/1.5005434

Sitinur Athirah, M., Mazuiyah, M. D., \& Sabarinah Sh, A. (2016). Inclusion of Social Realm within Elderly Facilities to Promote their Wellbeing. Procedia - Social and Behavioral Sciences, 234, 114-124. https://doi.org/10.1016/j.sbspro.2016.10.226

Tan, T. H., \& Lee, J. H. (2018). Assessing the determinants of retirement home ownership among Malaysian young-old seniors. International Journal of Housing Markets and Analysis, 11(4), 687-700. https://doi.org/10.1108/IJHMA-08-2017-0072

Tatnall, A., \& Lepa, J. (2003). The Internet, e-commerce and older people: an actornetwork approach to researching reasons for adoption and use. Logistics Information Management, 16(1), 56-63. https://doi.org/10.1108/09576050310453741

Thompson, E. (2013). From Canada to Kircubbin: learning from America on housing an ageing population. Housing, Care and Support, 16(3/4), 154-160.

van Hoof, J., \& Boerenfijn, P. (2018). Re-inventing existing real estate of social housing for older people: Building a new De Benring in Voorst, The Netherlands. In Buildings (Vol. 8, Issue 7). https://doi.org/10.3390/buildings8070089

Vasara, P. (2015). Not ageing in place: Negotiating meanings of residency in age-related housing. Journal of Aging Studies, 35, 55-64. https://doi.org/10.1016/j.jaging.2015.07.004

Verma, I. (2018). Housing design for all. Universal Design in Higher Education in Transformation Congress 2018, November. https://arrow.dit.ie/unides18pap/10/

Verma, I. (2019). Design for All?

Wai, C. W., \& Wei, C. Q. (2016). Preferred Housing Attributes among Elderly in Malaysia. http://www.prres.net/papers/Wai_Preferred_Housing_Attributes.pdf

Wang, J., Du, Y., Coleman, D., Peck, M., Myneni, S., Kang, H., \& Gong, Y. (2019). Mobile and connected health technology needs for older adults aging in place: Cross-sectional survey study. Journal of Medical Internet Research, 21(5), 1-9. https://doi.org/10.2196/13864

Weeks, L. E., \& LeBlanc, K. (2010). Housing concerns of vulnerable older Canadians. Canadian Journal on Aging, 29(3), 333-347.

Wei, Z., Kiang, H. C., \& Chye, F. J. (2017). Community Planning Framework of Community Care for the Elderly in Singapore. October. https://www.researchgate.net/publication/320628307

Wilby, F., \& Cathy Chambless. (2012). Older adults who seek care in the home. Quality in Ageing and Older Adults, 13(2), 89-97.

Wright, D. L., Faculty, C. I., Buys, L., Faculty, C. I., Vine, D., Faculty, C. I., Xia, B., Faculty, E., Skitmore, M., Faculty, E., Drogemuller, R., Faculty, C. I., Kennedy, R., Faculty, C. I., Li, M., \& Faculty, C. I. (2014). EUTOPIA $75+$ : Exploratory Futures Scenarios for Baby Boomers ' Preferred Living Spaces EU TOPIA 75 +: Exploratory Futures Scenarios for Baby Boomers' Preferred Living Spaces Abstract Introduction and Background: What the Numbers Say. 1-23.

Yuen, B. (2019). Moving towards age-inclusive public housing in Singapore. Urban $\begin{array}{llll}\text { Research } & \text { and }\end{array}$ 
Amalina binti Azmi, Peter Aning, Wan Nor Azriyati Wan Abd Aziz, Nur Hafizah Juhari, Nurhayati Khair, Puteri Ameera Mentaza Khan, Sheelah a/p Sivanathan,

Assessing the Strata Housing Attributes for Elderly to Age in Place in Klang Valley

https://doi.org/10.1080/17535069.2018.1451556

Yuki, A., Otsuka, R., Tange, C., Nishita, Y., Tomida, M., Ando, F., \& Shimokata, H. (2016). Epidemiology of frailty in elderly Japanese. The Journal of Physical Fitness and Sports Medicine, 5(4), 301-307. https://doi.org/10.7600/jpfsm.5.301

Yüksel, M., Kırkkanat, B., Yılmaz, S. H., \& Sevim, E. (2016). Investigation of life satisfaction, meaning in life and loneliness levels of a group of older adults in terms of some demographic variables. Toplum ve Sosyal Hizmet, 27(1), 65-76.

Yung, E. H. K., Conejos, S., \& Chan, E. H. W. (2016). Social needs of the elderly and active aging in public open spaces in urban renewal. Cities, 52(June 2018), 114 122. https://doi.org/10.1016/j.cities.2015.11.022

Zaid, S. M., Yamin, A. A., \& Yaacob, N. M. (2019). The environmental study on ageing in place: the design practice compliance to accessibility legislation and standards in Malaysia for elderly home environment. Ekoloji, 28(107), 601-613.

Zainab Ismail, Wan-Ibrahim Wan Ahmad, Zuria Mahmud, Salasiah Hanim Hamjah, Rosidah Jemain, Elmi Baharuddin, Razaleigh Muhamat@Kawangit, Roziah Sidek@Mat Sidek, \& Zuli. (2012). An alternative living arrangement for older Malaysian. Advances in Natural and Applied Sciences, 6(8), 1568-1572.

Received: $12^{\text {th }}$ July 2021 . Accepted: $17^{\text {th }}$ Sept 2021 